\title{
Fragmentative and Stereochemical Isomerization Probes for Homolytic Carbon to Phosphorus Bond Scission Catalyzed by Bacterial Carbon-Phosphorus Lyase
}

\author{
Spencer L. Shames, ${ }^{*}$ Lawrence P. Wackett, ${ }^{*}$ Marabeth S. Labarge, $\dagger$ \\ ROBERT L. KuczKowsKi, $\dagger$ AND Christopher T. WALSH* \\ *Departments of Chemistry and Biology, Massachusetts Institute of Technology, Cambridge, \\ Massachusetts 02139 and $\nmid$ Department of Chemistry, University of Michigan, \\ Ann Arbor, Michigan 48109
}

Received October 8, 1986

\begin{abstract}
Three bacterial strains, Agrobacterium radiobacter, Klebsiella oxytoca, and Kluyvera ascorbata, isolated by enrichment culture for carbon to phosphorus bond cleavage ability, were analyzed for the mode of C-P bond fission. The cleavage of alkyl phosphonic acids to alkanes and inorganic phosphates proceeded both aerobically and anaerobically, and growth on trideuteromethylphosphonic acid yielded trideuteromethane as product. These data indicate that functionalization of the organic moiety does not precede carbon to phosphorus bond cleavage. As probes for radical intermediates, cyclopropylmethylphosphonic acid and cis-1,2-dideutero-1-propenylphosphonic acid were used in growth experiments and the gaseous hydrocarbon products were examined. With the cyclopropylmethylphosphonic acid probe, all three bacteria produced methylcyclopropane, but only $K$. oxytoca and $K$. ascorbata also generated the acyclic olefin 1-butene, and then only in very low quantity $(0.6$ and $0.3 \%$ versus methylcyclopropane, respectively). With the propenylphosphonic acid probe, cis-1,2-dideuteropropene was formed with greater than $98 \%$ retention of configuration with each bacterial strain. Only for $K$. oxytoca was the alternate product, in this case trans-1,2dideuteropropene, clearly detected at $1.5 \%$. Thus, C-P bond fission may yield radical intermediates that are trapped efficiently at the enzyme active site or, alternatively, homolysis of the C-P bond may occur as a minor reaction pathway. 1987 Academic Press, Inc.
\end{abstract}

Since the initial discovery of the bacterial-mediated dephosphorylation of methyl- and ethylphosphonic acids by Zeleznick et al. (1), numerous studies concerning the substrate specificity and biological relevance of this carbon to phosphorus bond-cleaving reaction have been reported (2-4). Interest in the bacterial metabolism of phosphonic acids has been fueled by the discovery of several naturally occurring phosphonic acids. Among them, 2-aminoethylphosphonic acid, which is incorporated into cellular lipids, is the most widely spread biologically and has received the greatest attention $(4,5)$. In addition, the marketing of numerous phosphonic acid-containing insecticides and herbicides such as glyphosate $^{1}$ has focused further attention on the biodegradation and microbial metabolism of unactivated carbon to phosphorus bonds $(6-8)$.

${ }^{1}$ Glyphosate is the commercial name for the broad-spectrum herbicide $N$-phosphonomethylglycine (Monsanto Co., St. I ouis, MO). 


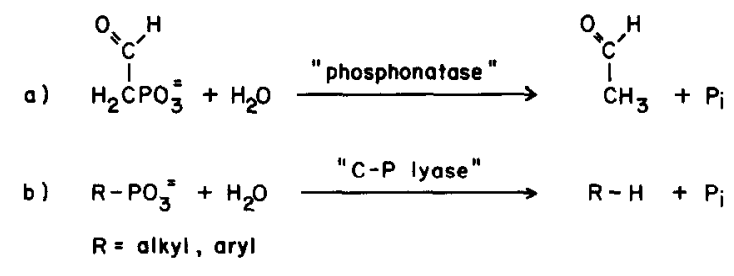

SCHEME 1

Two chemically distinct pathways of phosphonic acid catabolism have been discovered (Scheme 1). Phosphonoacetaldehyde hydrolase (phosphonatase), which catalyzes the hydrolytic cleavage of phosphonoacetaldehyde into acetaldehyde and inorganic phosphate (Scheme 1, reaction a), has been isolated and characterized (9-11). The catalytic mechanism apparently proceeds via a Conant-Swan type of fragmentation as exemplified chemically for 2-haloethylphosphonic acids $(12,13)$. The biological activity responsible for the dephosphorylation of unfunctionalized alkyl and aryl phosphonic acids, a reaction to which we have given the trivial name "C-P lyase" (Scheme 1, reaction b), however, has remained elusive. Despite considerable effort, activity in cell-free extracts has not been achieved. ${ }^{2}$

Two chemical reactions that may provide insight into the biological mechanism of unactivated carbon to phosphorus bond cleavage have been described. The addition of alkoxyl or thiyl radicals to various tervalent phosphorus species results in formation of phosphoranyl radicals which have been shown to be disproportionate via $\alpha$ and/or $\beta$ scission (14-16). Thus, $\alpha$ scission of the phosphoranyl radical generated from an alkoxyl radical and diethyl ethylphosphonite yields ethane plus trialkyl phosphite (Scheme 2A). An analogous biological mechanism would require an initial two-electron reduction of the phosphonic acid to the corresponding phosphonite. ${ }^{3} \mathrm{~A}$ second chemical model was described recently by Cordeiro et al. (18); the treatment of alkyl phosphonic acids with lead tetraacetate at $81^{\circ} \mathrm{C}$ resulted in the formation of a mixture of the corresponding alkane and alkene. This reaction is analogous to the Kolbe oxidative decarboxylation of carboxylic acids and, as suggested by these authors, may proceed via a oneelectron oxidation ${ }^{4}$ to a radical intermediate (Scheme 2B). These same authors (18) suggested that the cleavage of carbon to phosphorus bonds by Eschericia coli may proceed via a similar radical intermediate, based on the observations that alkyl phosphonic acids yielded low quantities of the corresponding alkenes and

\footnotetext{
${ }^{2}$ In addition to several reports stating that cell-free activity was not obtainable, numerous research reports discuss their work on whole cells as a prelude to future cell-free studies; however, to date none have been reported.

${ }^{3}$ Inasmuch as the reduction potential reported for the reduction of phosphorous acid to dihydrogen phosphinic acid of $-0.5 \mathrm{~V}(17)$ is a model for phosphonite formation, this mechanism may be biologically feasible.

${ }^{4}$ The electrochemical potential of 1.7-2.2 $\mathrm{V}$ required for anodic oxidation of alkylphosphonic acids (19) suggests that an analogous biological mechanism for oxidative dephosphorylation is unlikely.
} 


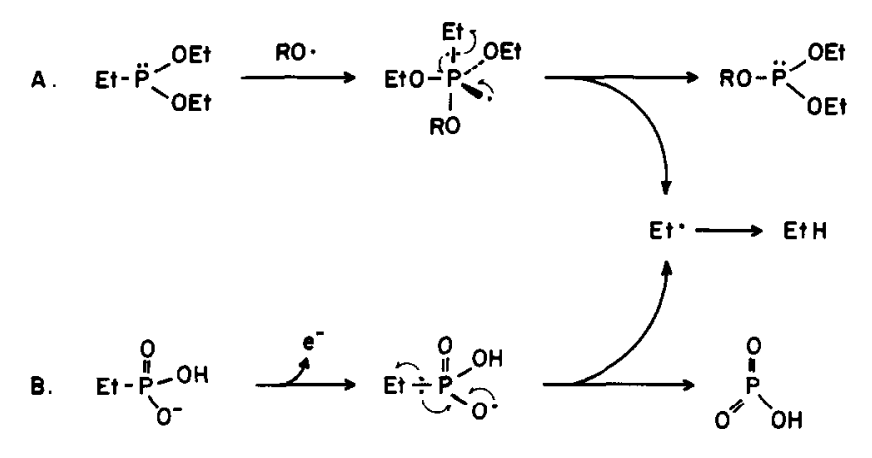

SCHEME 2

that bacterial growth on cyclopropylmethylphosphonic acid showed 2\% 1-butene accompanying methylcyclopropane formation.

Concurrent with the studies of Cordeiro et al., we have been examining the mechanism of C-P lyase using several different bacterial strains and a variety of chemical probes, which included cyclopropylmethylphosphonic acid (20). Because we, as others, were not able to detect any cell-free C-P lyase activity, we relied on phosphonic acid probes that would support bacterial growth as sources of inorganic phosphate via carbon to phosphorus bond cleavage and, upon in vivo $\mathrm{C}-\mathrm{P}$ bond cleavage, would yield readily isolable gaseous products.

\section{MATERIALS AND METHODS}

Growth of bacteria and product analysis. The bacterial strains chosen for these studies, Agrobacterium radiobacter, Klebsiella oxytoca, and Kluyvera ascorbata, were isolated by enrichment culture from sewage sludge. ${ }^{5}$ In a typical experiment, 4-ml cultures of bacteria containing $500 \mu \mathrm{M}$ phosphonic acid were grown in sealed $20-\mathrm{ml}$ Wheaton vials. Gases were analyzed by gas chromatography on a Carle Series 100 Hach gas chromatograph fitted with Porapak N/Q (Hach Co., Loveland, CO) and VZ-10 (Alltech Assoc., Deerfield, IL) columns. The gases were identified by both retention time and coelution with standards. To test whether minor product formation was $\mathrm{C}-\mathrm{P}$ lyase dependent, bacteria were grown on $500 \mu \mathrm{M}$ phosphonic acid plus $500 \mu \mathrm{M}$ inorganic phosphate. Under these conditions, phosphonic acid utilization was inhibited $>90 \% .^{6}$ The detection limit of gases was typically $1.5 \times 10^{-12}$ mol per $50-\mu$ l injection, or $0.05 \%$ of the major product. Analysis of trideuteromethane was carried out on a Hewlett-Packard 5992A GC/MS that was fitted with a 2-m 3\% Apiezon column. Stereochemical determinations of cis- and trans-1,2-dideuteropropene were carried out on a

\footnotetext{
${ }^{5}$ A detailed account of isolation procedures and overall substrate specificity of the various bacterial strains may be found in Wackett et al. (32).

${ }^{6}$ Inorganic phosphate represses the quantity of phosphonic acid dissimilated during bacterial growth. A detailed study is reported with the substrate specificity data (32).
} 
Hewlett-Packard 8460A microwave spectrometer. Propene was isolated by cooling a Wheaton vial to $-78^{\circ} \mathrm{C}$ and pumping the remaining gases through Ascarite into a trap at $-196^{\circ} \mathrm{C}$. The stereochemistry ratios were determined from the computer-averaged integrated intensities of the three $J=1 \rightarrow 2$ rotational transitions for the cis- and trans-dideutero isomers. The method is described more fully in Imachi et al. (21).

Phosphonic acid substrates. 1-Propylphosphonic acid was obtained from Alfa. cis-1-Propenylphosphonic acid was a gift from Merck Sharp and Dohme (Rahway, $\mathrm{NJ}$ ). All chemicals used in the synthesis of the phosphonic acid substrates were obtained from Aldrich. ${ }^{1} \mathrm{H}$ NMR spectra were recorded on a Bruker WH 250 spectrometer using internal DSS as standard. Proton-decoupled ${ }^{13} \mathrm{C}$ NMR spectra were recorded on a Bruker WH 270 spectrometer operating at $69 \mathrm{MHz}$ using external deuterochloroform as standard. The dimethyl ester of cyclopropylmethylphosphonic acid was synthesized by refluxing a mixture of bromomethylcyclopropane $(4.5 \mathrm{~g}, 33.3 \mathrm{mmol})$ and trimethylphosphite $(4.55 \mathrm{~g}, 36.6 \mathrm{mmol})$ at $130^{\circ} \mathrm{C}$ for $10 \mathrm{~h}$. The dimethyl cyclopropylmethylphosphonate was isolated by distillation (bp $45-50^{\circ} \mathrm{C}, 0.2 \mathrm{~mm}$ ) and purified further by flash chromatography with ethyl acetate: methanol $(98: 2)$. The methyl esters were cleaved by treatment with iodotrimethylsilane. Dimethyl cyclopropylmethylphosphonate $(0.45 \mathrm{~g}, 2.7 \mathrm{mmol})$ was dissoled in $4 \mathrm{ml} \mathrm{CCl}_{4}$ under argon at $0^{\circ} \mathrm{C}$. Iodotrimethylsilane $(1.2 \mathrm{~g}, 6 \mathrm{mmol})$ was added over a 10-min period with stirring and the reaction was allowed to continue for an additional $15 \mathrm{~min}$ at $0^{\circ} \mathrm{C}$. After it was warmed to room temperature, the reaction mixture was added dropwise to a solution containing 2.5 eq $\mathrm{NH}_{4} \mathrm{HCO}_{3}$ $(6.9 \mathrm{mmol})$ in $5 \mathrm{ml} \mathrm{H}_{2} \mathrm{O}$. The aqueous solution was extracted with diethyl ether (10 $\times 20 \mathrm{ml}$ ) and evaporated to $0.4 \mathrm{ml}$ under reduced pressure. The diammonium salt of cyclopropylmethylphosphonate crystallized upon the addition of acetone. The crystals were recrystallized by dissolving in $0.5 \mathrm{ml} \mathrm{H}_{2} \mathrm{O}$ and triturating with acetone. Cyclopropylmethylphosphonic acid gave the following peaks on ${ }^{1} \mathrm{H}$ NMR $\left(\mathrm{D}_{2} \mathrm{O}\right): \delta=0.15(\mathrm{~m}, 2 \mathrm{H}) ; 0.51(\mathrm{~m}, 2 \mathrm{H}) ; 0.83(\mathrm{~m}, 1 \mathrm{H}) ; 1.52\left(\mathrm{~d}\right.$ of d, $2 \mathrm{H}, J_{\mathrm{H}-\mathrm{P}}=17$ $\mathrm{Hz}$ ). cis-1,2-Dideutero-1-propenylphosphonic acid was synthesized by a method identical to that described by Slates and Wendler (22) except that the reduction step was carried out with deuterium gas over Lindlar catalyst. No contaminating trans-1-propenylphosphonic acid was detected by ${ }^{13} \mathrm{C}$ NMR to a detection limit of ca. $1 \%$. The following peaks were observed by ${ }^{13} \mathrm{C} N M R\left(\mathrm{D}_{2} \mathrm{O}\right): \delta=15.6\left(\mathrm{~d}, J_{\mathrm{P}-\mathrm{CCC}}\right.$ $=9.5 \mathrm{~Hz}) ; 117.5\left(\mathrm{~d}\right.$ of $\left.\mathrm{t}, J_{\mathrm{P}-\mathrm{C}}=154 \mathrm{~Hz}\right) ; 147.6(\mathrm{t})$. Trideuteromethylphosphonic acid was prepared by refluxing trideuteromethyliodide $(3.0 \mathrm{~g}, 20.7 \mathrm{mmol})$ and freshly distilled triisopropyl phosphite $(4.8 \mathrm{~g}, 22.8 \mathrm{mmol})$ at $100^{\circ} \mathrm{C}$ for $1 \mathrm{~h}$. The diisopropyl ester was isolated by distillation (bp $33-35^{\circ} \mathrm{C}, 0.2 \mathrm{~mm}$ ) and purified further by flash chromatography (ethyl acetate : hexanes, $12: 1)$ to yield $2.5 \mathrm{~g}(61 \%$ theoretical) of diisopropyl trideuteromethylphosphonate. The free acid was prepared by refluxing the diester in $6 \mathrm{~N} \mathrm{HCl}$ for $12 \mathrm{~h}$ and isolated by evaporating the solvent under reduced pressure. The solidified trideuteromethylphosphonic acid was dried in vacuo over $\mathrm{NaOH}$. Diisopropyl 1-alkynylphosphonate was prepared by the method of Slates and Wendler (22). The isopropyl esters were cleaved by treatment with iodotrimethylsilane as described for the synthesis of cyclopropylmethylphosphonic acid. The diammonium salt of 1-propynylphosphonic acid 
gave the following peaks on ${ }^{13} \mathrm{C}$ NMR $\left(\mathrm{D}_{2} \mathrm{O}\right): \delta=3.0\left(\mathrm{~d}, J_{\mathrm{P}-\mathrm{CCC}}=2.8 \mathrm{~Hz}\right) ; 79.6(\mathrm{~d}$, $\left.J_{\mathrm{P}-\mathrm{C}}=239 \mathrm{~Hz}\right) ; 90: 3\left(\mathrm{~d}, J_{\mathrm{P}-\mathrm{CC}}=44 \mathrm{~Hz}\right)$.

\section{RESULTS AND DISCUSSION}

Our initial studies with several different bacterial strains demonstrated that growth on propyl-, propenyl-, or propynylphosphonic acids yields propane, propene, or propyne as product, respectively. ${ }^{5}$ These data suggest that functionalization of the organic moiety does not precede carbon to phoshorus bond cleavage. To confirm this point, $A$. radiobacter was grown aerobically on trideuteromethylphosphonic acid, and the mass of the methane product was analyzed by GC-MS. The resulting fragmentation pattern observed at $m / e$ of 17,18 , and 19 was consistent with formation of trideuteromethane (23). Growth of the enteric bacteria, $K$. oxytoca and $K$. ascorbata, under anaerobic conditions on methyl-, ethyl-, and vinylphosphonic acids as the sole source of phosphorus gave methane, ethane, and ethylene, respectively, as products. These data indicate that $\mathrm{O}_{2}$ is not essential for C-P lyase activity.

Bacterial growth under anaerobic conditions does not inhibit electron transfer reactions; thus, a redox process for C-P bond scission is permissible and may occur homolytically as the chemical precedents shown in Scheme 2 suggest. We initially examined alkylphosphonic acids to see if they produced alkenes along with alkanes. In contrast to the results reported by Cordeiro $e t$ al., which showed that $E$. coli growth on alkyl phosphonic acids gave olefinic products in ratios of alkene to alkane ranging from $3 \%$ for ethylphosphonic acid to $0.05 \%$ for $n$ hexylphosphonic acid, we found that growth of our three bacterial strains on ethyl, $n$-propyl-, and $n$-butylphosphonic acids failed to show any detectable ethylene, propene, or 1-butene, respectively, showing only the corresponding alkanes. Thus, to examine the possibility of homolytic $\mathrm{C}-\mathrm{P}$ bond scission more closely, we employed two phosphonic acid-containing radical probes. If C-P bond scission occurs homolytically, cyclopropylcarbinyl radical, generated from cyclopropylmethylphosphonic acid, can fragmentatively isomerize to 1-butene. This functional group has been used previously to probe for radical intermediates in both chemical $(24,25)$ and enzymatic (26) reactions. Alternatively, the stereochemical isomerization of cis-1,2-dideutero-1-propenylphosphonic acid during C-P lyase action to yield trans-1,2-dideuteropropene would be diagnostic of homolysis (27). Whereas fragmentative isomerization of cyclopropylcarbinyl radical occurs at a rate of $1.3 \times 10^{8} \mathrm{~s}^{-1}(28)$, the rate of stereochemical isomerization of a propenyl radical has been estimated to be greater than $10^{9} \mathrm{~s}^{-1}(27,29)$.

Cyclopropylmethylphosphonic acid was found to be a substrate of the C-P lyase of all three bacterial strains examined. Studies with $A$. radiobacter showed the formation of both methylcyclopropane and 1-butene in a ratio of ca. 200 to 1. However, growth of this bacterium on an equimolar mixture of inorganic phosphate and cyclopropylmethylphosphonic acid $(500 \mu \mathrm{M}$ each to repress C-P lyase activity) resulted in a $93 \%$ reduction in methylcyclopropane yield but the quantity of 1-butene was not affected. These data suggested that the 1-butene had arisen 
from a different biological reaction. In contrast, the formation of 1-butene by $K$. oxytoca and $K$. ascorbata $(0.6( \pm 0.1) \%$ and $0.3( \pm 0.1) \%$ of the methylcyclopropane, respectively), was suppressed completely by inorganic phosphate. These last two results are comparable to the ratio of $2 \%$ determined for $E$. coli (18) and can be interpreted to favor formation of a short-lived radical intermediate.

The use of cyclopropylmethylphosphonic acid to probe for a putative radical intermediate does have a major drawback. If the fragmentatively isomerized allylcarbinyl radical is formed during catalysis but cannot be quenched efficiently, it can isomerize back to the initial cyclopropylcarbinyl species at a rate of $4.9 \times 10^{3}$ $\mathrm{s}^{-1}(30)$. Thus, if quenching of the allylcarbinyl radical and subsequent 1-butene release from the enzyme surface is slower than ca. $10 \mathrm{~s}^{-1}$, a rapid equilibrium can be established at the enzyme-active site and the effectiveness of the probe will be drastically reduced. Because of this recyclization issue, it is unclear how generally reliable the fragmentative isomerization of the cyclopropylmethyl moiety will be as a probe for radicals in enzymatic catalysis (31).

We turned next to stereospecifically deuterated 1-propenylphosphonic acid as a probe where stereochemical isomerization at an $\mathrm{sp}^{2}$ center, rather than fragmentative isomerization, would be a reporter for homolytic cleavage. Thus, if the action of C-P lyase on 1,2-dideutero-1-propenylphosphonic acid yields a finite 1-propenyl free radical intermediate, a mixture of cis- and trans-1,2-dideuteropropene might be produced (Scheme 3). cis-1,2-Dideutero-1-propenylphosphonic acid was a substrate of bacterial C-P lyase and the stereochemistry of the dideuteropropene product was analyzed by microwave spectroscopy. As summarized in Table 1 , stereochemical retention was the overwhelmingly predominant outcome of C-P cleavage for all three bacterial strains. Only in the case of $K$. oxytoca was there any result interpretable as radical processing; in this instance it was interpreted by detection of $1.5( \pm 0.3) \%$ of isomerized trans-1,2-dideuteropropene. The A. radiobacter and $K$. ascorbata results serve as de facto controls ensuring that the $1.5 \%$ of trans isomer product was not due to contaminating trans-1,2-dideutero-1propenylphosphonic acid in the starting substrate.

The net $1 \%$ flux to isomerized trans-1,2-dideuteropropene by $K$. oxytoca appears in analogy to the cyclopropylmethylphosphonic acid result: a slender but real result in support of homolytic C-P bond scission. What is unresolved by both

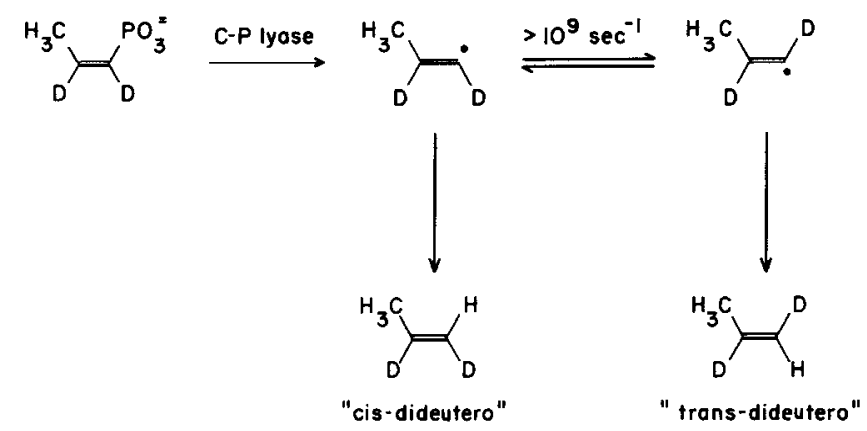

SCHEME 3 


\section{TABLE 1}

Quantitation of the Isomerized Products Formed from the Reaction of Cyclopropylmethylphosphonic Acid and cis-1,2-Dideutero-1-propenyl Phosphonic Acid with C-P Lyase

\begin{tabular}{|c|c|c|}
\hline \multirow[b]{2}{*}{ Bacterium } & \multicolumn{2}{|c|}{ Phosphonic acid probe $\left(R-\mathrm{PO}_{3}^{2-}\right)$} \\
\hline & $R=\underset{(\% \text { 1-butene })^{a}}{\text { Cyclopropylmethyl }}$ & $\begin{array}{l}R=\text { cis-1,2-Didcutcro-1-propcnyl } \\
\quad \text { (\% trans-dideuteropropene) }{ }^{b}\end{array}$ \\
\hline A. radiobacter & 0 & $0.5( \pm 0.3)$ \\
\hline$K$. oxytoca & $0.6( \pm 0.1)$ & $1.5( \pm 0.2)$ \\
\hline K. ascorbata & $0.3( \pm 0.1)$ & $0.5( \pm 0.2)$ \\
\hline
\end{tabular}

\footnotetext{
${ }^{a}$ Values are the relative percentage of 1-butene to methylcyclopropane as determined by peak height on GC and were run in triplicate.

${ }^{b}$ Values are the relative percentage of trans to cis isomers as determined by microwave spectroscopy. Typically 100 to 400 scans were collected for the weak lines of trans-1,2-dideuteropropene. At least three separate determinations were made for each bacterial strain.
}

the fragmentative and stereochemical isomerization probes, however, is whether homolytic C-P bond scission occurs in every catalytic event or whether it is a minor side pathway or alternate decomposition route for a reaction intermediate normally proceeding in a two-electron redox manifold. If carbon-centered radicals are formed in every turnover, they must be constrained in the active site to recyclize almost quantitatively (cyclopropylcarbinyl $\rightleftharpoons$ allylcarbinyl) or be trapped at $>10^{11} \mathrm{~s}^{-1}$ (given only $1 \%$ isomerization of cis- to trans-propenyl radical). Additionally, the efficiencies of radical capture may vary at the active site of bacterial C-P lyases as shown in this work and in E. coli (18). If homolysis is not the major flux, one will need additional nonenzymatic data on mechanisms for cleavage of unactivated carbon to phosphorus bonds as well as success in obtaining cell-free activity and subsequent enzyme characterization studies.

\section{ACKNOWLEDGMENTS}

This work was supported in part by a grant from the National Institutes of Health (GM 20011). Funds to purchase and maintain the microwave spectrometer were provided by the National Science Foundation. S.L.S. and L.P.W. are recipients of National Institutes of Health Postdoctoral Fellowships. The authors thank Dr. Alan Walts for many helpful discussions and Drs. Tim Miller and Thomas Neenan (Harvard University, Cambridge, MA) for their assistance in the GC-MS experiment.

\section{REFERENCES}

1. Zeleznick, L. D., Myers, T. C., And Titchener, E. B. (1963) Biochim. Biophys. Acta 78, 546.

2. Mastalerz, P., Wieczorek, A., And Kochman, M. (1965) Acta Biochim. Polon. 12, 151.

3. Cook, A. M., Daughton, C. G., And Alexander, M. (1978) J. Bacteriol. 133, 85. 
4. Hilderbrand, R. L., And Henderson, T. O. (1983) in The Role of Phosphonates in Living Systems (Hilderbrand, R. L., Ed.), p. 5, CRC Press, Boca Raton, FL.

5. Kittredge, J. S., And Roberts, E. (1969) Science 164, 37.

6. Cook, A. M., Daughton, C. G., AND AleXander, M. (1978) Appl. Environ. Microbiol. 36, 668.

7. Daughton, C. G., Cook, A. M., And Alexander, M. (1979) J. Agric. Food Chem. 27, 1375.

8. Balthazor, T. M., and Hallas, L. P. (1986) Appl. Environ. Microbiol. 51, 432.

9. La Nuaze, J. M., Rosenberg, H., and Shaw, D. C. (1970) Biochim. Biophys. Acta 212, 332.

10. La Nuaze, J. M., Coggins, J. R., and Dixon, H, B. F. (1977) Biochem. J. 165, 409.

11. Hepburn, T. W., Olsen, D. B., Dunaway-Mariano, D., and Mariano, P. S. (1986) Fed. Proc. 45, 1650, Abstract 990, Federation of American Societies for Experimental Biology.

12. Calvo, K. C., and Westheimer, F. H. (1984) J. Amer. Chem. Soc. 106, 4205.

13. Calvo, K. C. (1986) J. Amer. Chem. Soc. 107, 3690.

14. Davies, A. G., Dennis, R. W., And Roberts, B. P. (1974) J. Chem. Soc. Perkin Trans. 1 11, 1101.

15. Bentrude, W. G., Hansen, E. R., Khan, W. A., And Rogers, P. E. (1972) J. Amer. Chem. Soc. 94, 2867.

16. Krusic, P. J., Mahler, W., ANd Kochl, J. K. (1972) J. Amer. Chem. Soc. 94, 6033.

17. Cleveland Rubber Company (1978) in Handbook of Chemistry and Physics (Weast, R. C., Ed.), 59th ed., p. D-193, CRC Press, West Palm Bech, FL.

18. Cordeiro, M. L., Pompliano, D. L., and Frost, J. W. (1986) J. Amer. Chem. Soc. 108, 332.

19. Frost, J.W., Loo, S., Cordeiro, M.L., And Li, D. (1987) J. Amer. Chem. Soc. 109, 2166-2171.

20. Shames, S. L., Wackett, L. P., Venditti, C. P., and Walsh, C. T. (1986) Fed. Proc. 45, 1865, Abstract 2245, Federation of American Societies for Experimental Biology.

21. Imachi, M., Kuczkowski, R. L., Groves, J. T., and CanT, N. W. (1983) J. Catal. 82, 355.

22. Slates, H. L., AND WendleR, N. L. (1978) Chem. Ind. (London) 17, 430.

23. Dibeler, V. H., ANd Mohler, F. L. (1950) J. Res. Natl. Bur. Stand. Sect. A 45, 441.

24. Garst, J. F., Deutch, J. E., and Whitesides, G. M. (1986) J. Amer. Chem. Soc. 108, 2490.

25. Krusic, P. J., Fagan, P. J., and San Filippo, J. (1977) J. Amer. Chem. Soc. 99, 250.

26. Fitzpatrick, P. F., and Villafranca, J. J. (1985) J. Amer. Chem. Soc. 107, 5022.

27. Whitesides, G. M., Casey, C. P., and Krieger, J. K. (1971) J. Amer. Chem. Soc. 93, 1379.

28. Maillard, B., Forrest, D., and Ingold, K. U. (1976) J. Amer. Chem. Soc. 98, 7024.

29. Fessenden, R. W. (1963) J. Chem. Phys. 39, 2147.

30. Griller, D., ANd Ingold, K. U. (1980) Acc. Chem. Res, 13, 317.

31. Sherry, B., AND Abeles, R. H. (1985) Biochemistry 24, 2594.

32. Wackett, L. P., Shames, S. L., Venditti, C. P., and Walsh, C. T. (1987) J. Bacteriol. 169, $710-717$. 